\title{
THE INFLUENCE OF BOREHOLE DESIGN \\ ON THE PRODUCTION AND EFFICIENCY PARAMETERS OF WELLS INTAKING QUATERNARY WATERS IN THE SOUTH OF LÓDŹ****
}

\section{INTRODUCTION}

The Quaternary aquifer is commonly used for supplying water for municipal waterworks and for communal and industrial purposes. This stems from the fact that this is the first (or only) accessible aquifer, which can cover the water demand. Another advantage of the Quaternary aquifer as a source of water for communal purposes is the relatively low cost of realization of the intake wells. This mainly results from their small depth and the fact that no high strength materials have to be used.

The longevity of wells producing Quaternary waters containing considerable amounts of iron and manganese can be provided by a dedicated construction solution in view of the existing geological and hydrogeological conditions and the planned production variant.

This paper was based on the analyses of three Quaternary wells used by the Waterworks and Sewage Utility in view of the applied design and its influence on the efficiency of the well during extraction. By the efficiency of the well we mean the general efficiency, i.e. technical efficiency (preservation of the well) and hydraulic efficiency (maintaining production parameters over years of extraction). A groundwater intake consisting of wells of different design and age was analyzed in this paper [6].

\section{LOCALIZATION OF "GRODZISKO” GROUNDWATER INTAKE}

The "Grodzisko" intake is localized in the town of Grodzisko, about $15 \mathrm{~km}$ from Łódź city center, close to the SE city border (Fig. 1). This intake consists of four wells exploited by

* AGH University of Science and Technology, Faculty of Drilling, Oil and Gas, Krakow, Poland

** Zakład Wodociągów i Kanalizacji Sp. z o.o. (Waterworks and Sewage Utility), Łódź, Poland

*** This study was supported by the AGH University of Science and Technology statutory research no. 11.11.190.555 (Faculty of Drilling, Oil and Gas) 
the Waterworks and Sewage Utility. One of them, $\mathrm{Cr}_{1}$ intakes the Lower Cretaceous aquifer at a considerable depth of $759 \mathrm{~m}$ b.s., whereas the remaining three, denoted as b, c and d, intake the Quaternary aquifer.

At present, wellbore $b$ is not exploited because of a considerable drop of efficiency due to aging (corrosion and subsidence of the construction, clogging of the filter and the near-filter zone).

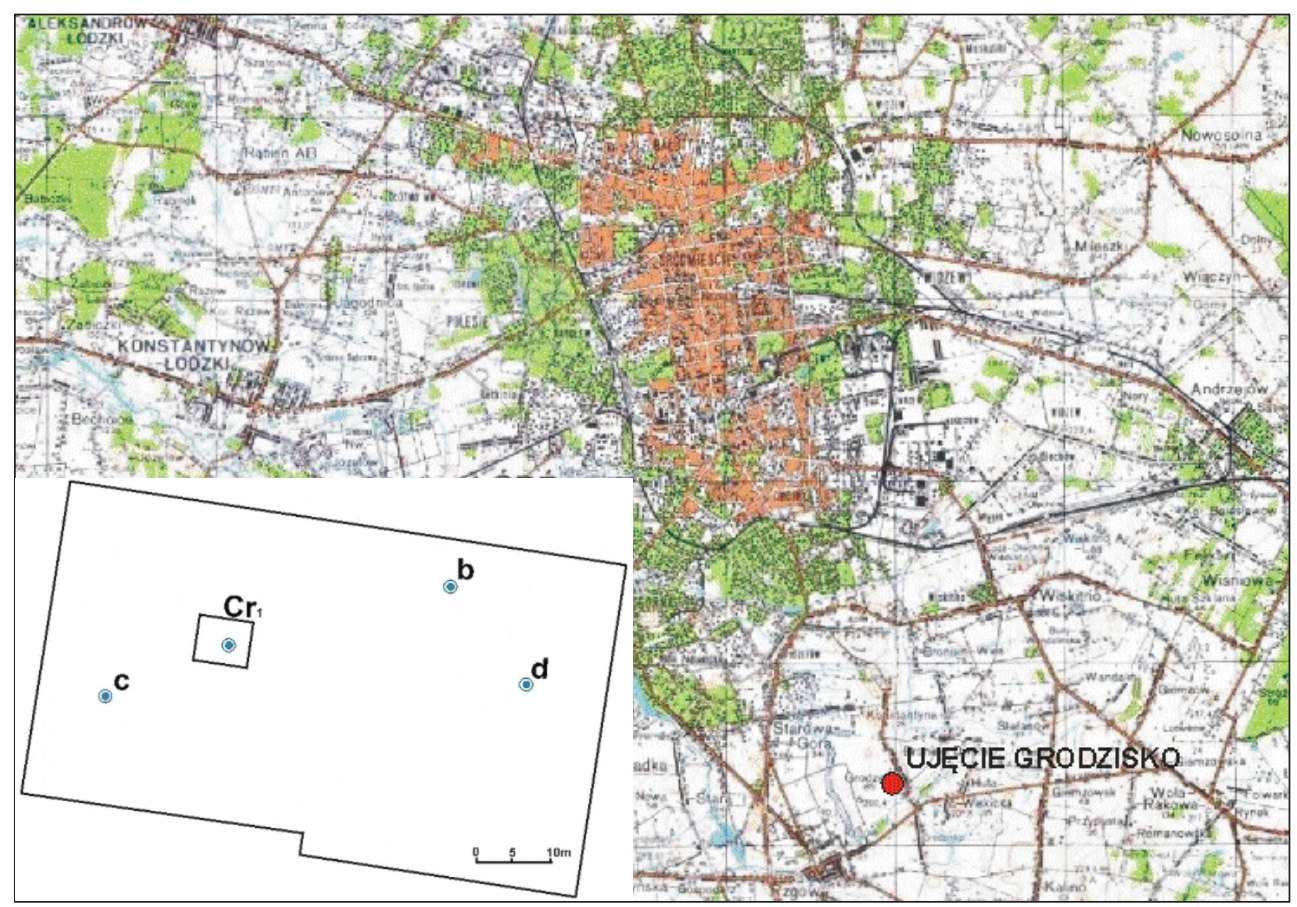

Fig. 1. Localization of the "Grodzisko" intake and the distribution of wellbores in the area $\left(C r_{1}\right.$ - Lower Cretaceous well; b, c, d-Quaternary wells)

\section{CHARACTERISTICS OF THE GEOLOGICAL AND HYDROGEOLOGICAL CONDITIONS OF 'GRODZISKO' INTAKE}

Geologically, the area of the "Grodzisko" intake is located in the central part of the NE edge of the Łódź Basin, having a significant influence on the Lower- and Upper Cretaceous strata, being a basement of the Quaternary beds [3].

The Quaternary strata, connected with glacial period of the South Poland, are made of boulder clays (mostly sandy), marginal clays and dusts, which settled on the fluvioglacial sands and gravels. These sediments do not form a continuous cover, but flakes. This manifests itself in the upper part of the geological profiles of particular wells in the "Grodzisko" intake (Fig. 2). No Paleogene or Neogene beds have been found in these wells; the Qua- 
ternary sediments are deposited directly on the Mesozoic basement (cracked carbonaceous rocks of Upper Cretaceous age).

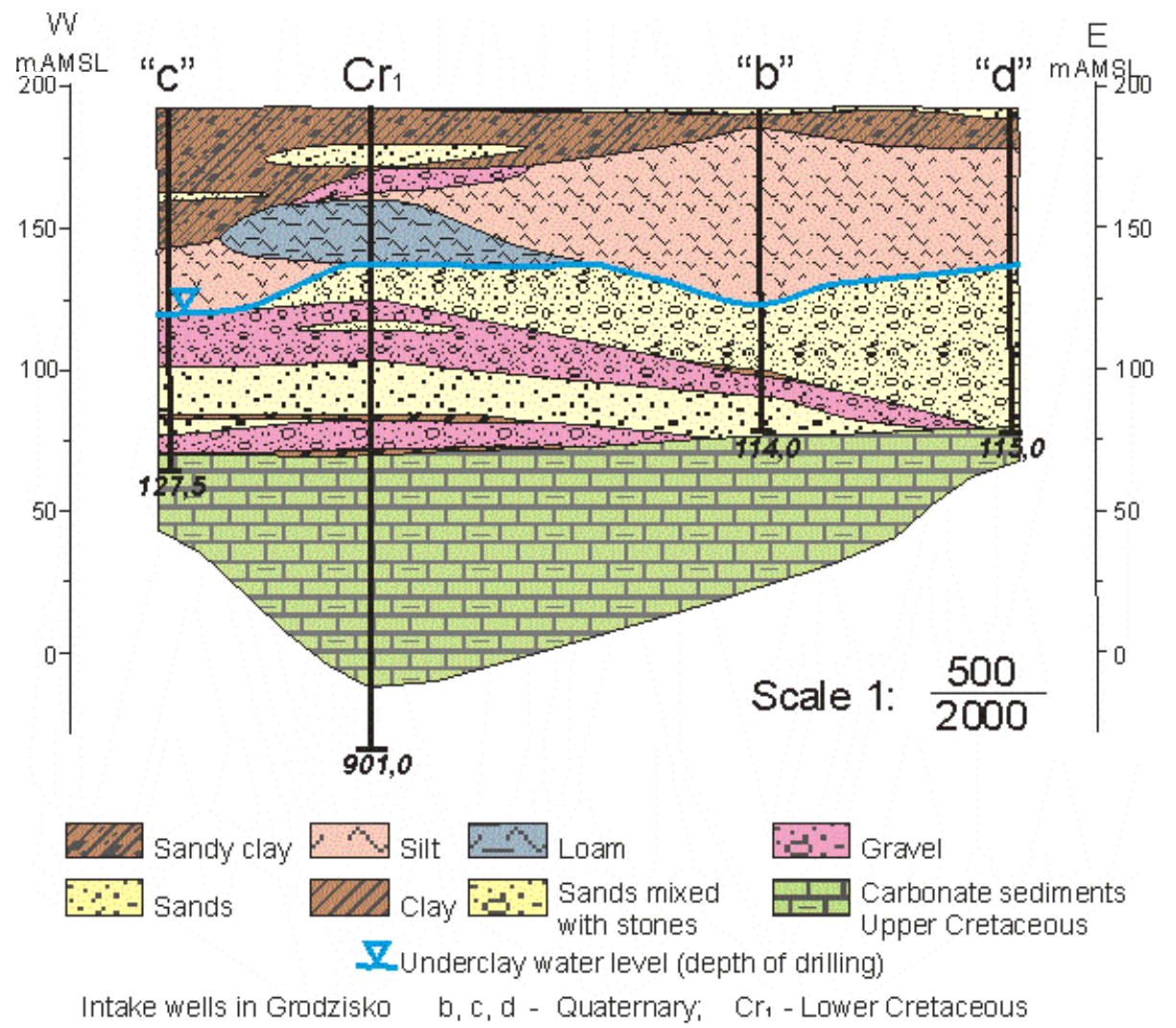

Fig. 2. WE geological cross-section of "Grodzisko" intake

Three aquifers can be found within the Quaternary sediments in the Łódź area, i.e. groundwater level, interclay level and subclay level. Only two levels were observed in the Grodzisko area, i.e.

- groundwater level, shallowly deposited in sands and gravels, and locally in sandy parts of moraine clays. This is a rather thin level, most frequently intaken with dug wells,

- subclay level in sands and fluvioglacial gravels, deposited under the clays of the Central Poland and South Poland glaciation age. In the area of the "Grodzisko" intake this level was drilled at a depth below 53.0-73.0 $\mathrm{m}$ b.s and has a confined character. The static water level stabilized at a depth of $\sim 4.0 \mathrm{~m}$ b.s. The permeable material in this layer has direct contact with the roof of the detrital Upper Cretaceous basement, thanks to which hydraulic connections are maintained in the Upper Cretaceous aquifer, and provide considerable output of the production well. 


\section{EVALUATION OF THE FILTRATION COEFFICIENT $\boldsymbol{k}$ OF AQUIFER IN THE NEAR FILTER ZONE}

Filtration coefficient $k$ was calculated based on archival results of production pumping and test pumping, performed in 2017 to show how filtration conditions change in the near filter zone with the ongoing production from intake wells b, c and d. All calculations are based on a Dupuit equation (eqs. (1) and (2)), and the results of pumping tests for identical conditions in geological profiles in all the wells [5]. The calculated values of coefficient $k$ are presented in Table 1 .

$$
\begin{aligned}
& k=\frac{0.366 \cdot Q \cdot \lg \frac{R}{r}}{m_{a} \cdot s} \cdot \frac{1}{b} \\
& b=\sqrt{\frac{l}{m_{a}}} \cdot \sqrt[4]{\frac{2 \cdot m_{a}-l}{m_{a}}}
\end{aligned}
$$

where:

$Q-$ yield of the well at a given stage of extraction $\left[\mathrm{m}^{3} / \mathrm{h}\right]$,

$R$ - radius of depression cone calculated for each of the wells [m],

$r$ - wellbore radius [m],

$m_{\alpha}-$ apparent thickness, calculated with Zamarin's formula for each well,

$s$ - depression in the well [m],

$b$ - Forcheimer's correction calculated with equation (2).

Table 1

Filtration rate $k$ for ongoing production in wells b, c and $\mathrm{d}$ in the "Grodzisko" intake in the years 1970-2017

\begin{tabular}{|l|c|c|c|c|c|c|c|}
\hline \multirow{2}{*}{ Well no. } & \multicolumn{5}{|c|}{ Filtration coefficient $k[\mathrm{~m} / \mathrm{h}]$} & \multirow{2}{*}{$\begin{array}{c}\text { Drop of coefficient } k \\
{[\%]}\end{array}$} \\
\cline { 2 - 8 } & 1970 & 1989 & 1992 & 1993 & 2012 & 2017 & 88 \\
\hline b & - & 0.5 & - & - & 0.06 & - & 77 \\
\hline c & 0.34 & - & 0.08 & - & - & & 67 \\
workover & & & 0.15 & & & 0.05 & 75 \\
\hline d & - & - & - & 0.48 & - & 0.12 & \\
\hline
\end{tabular}

The analysis of the calculated parameter $k$ reveals that its value has considerably changed over the 24-year history of the extraction of the analyzed wells of the "Grodzisko" intake [6]. In well $b$, it lowered by $88 \%$ as compared to the initial value, in well c by $77 \%$ at the initial stage of extraction and by $67 \%$ in the second phase of extraction (as compared to the value after workover), and by $75 \%$ in well $\mathrm{d}$.

The value of filtration coefficient $k$ depends on the properties of fluid and rock medium, therefore one can see that the hydrogeological conditions in the near filter zone deteriorated during the extraction of the well. These changes mainly stem from the privileged filtration 
pathways and influence of clogging processes on the near filtration zone and thickening of the gravel pack. It should be stressed, however, that these changes refer to the zones of impact of the intake of an indefinite radius, therefore these data cannot be referred to the whole aquifer. The obtained results illustrate the degree of changes taking place in the closest neighborhood of the well [2].

\section{QUALITY OF INTAKEN QUATERNARY WATERS}

Water coming from the Quaternary strata in the "Grodzisko" intake has good quality and does not show much variation in terms of physicochemical parameters in particular wells (Tab. 2). The variation of analyzed parameters has a local character and is probably connected with filtration conditions in the near well zones over the years of extraction.

Table 2

Physicochemical coefficients of water produced by Quaternary wells in the "Grodzisko" intake

\begin{tabular}{|l|c|c|c|c|}
\hline \multirow{2}{*}{\multicolumn{1}{|c|}{ Index }} & \multirow{2}{*}{ Unit } & \multicolumn{2}{c|}{ Results of analyses performed in 1989-2014 } \\
\cline { 3 - 5 } & & well b & well c & well d \\
\hline Reaction & {$[\mathrm{pH}]$} & $7.0-7.6$ & $7.0-7.7$ & $7.0-7.6$ \\
\hline Temperature & {$\left[{ }^{\circ} \mathrm{C}\right]$} & $7.5-15.0$ & $7.0-18.7$ & $7.5-16.0$ \\
\hline Chlorides & {$[\mathrm{mg} / 1]$} & $3.4-16.0$ & $3.1-15.9$ & $2.0-12.8$ \\
\hline Sulfates & {$[\mathrm{mg} / 1$} & $6.6-60.9$ & $23.3-62.4$ & $8.1-71.6$ \\
\hline Calcium & {$[\mathrm{mg} / 1]$} & $74.9-101.0$ & $45.2-107.9$ & $75.8-102.8$ \\
\hline Magnesium & {$[\mathrm{mg} / 1]$} & $2.8-19.4$ & $1.9-19.4$ & $2.8-23.0$ \\
\hline Iron & {$[\mathrm{mg} / \mathrm{l}]$} & $1.0-2.448$ & $2.0-3.0$ & $1.0-2.496$ \\
\hline Manganese & {$[\mathrm{mg} / 1]$} & $0.19-0.22$ & $0.12-0.33$ & $0.13-0.24$ \\
\hline Carbon dioxide & {$[\mathrm{mg} / \mathrm{l}]$} & $7.92-33.22$ & $11.0-48.62$ & $9.46-30.08$ \\
\hline Aggressive carbon dioxide & {$[\mathrm{mg} / 1]$} & $0.0-1.45$ & $0.0-11.87$ & $0.0-4.84$ \\
\hline
\end{tabular}

Water from the "Grodzisko" intake is high in iron and manganese oxide, with highest values in well c. The strength parameters of the materials used in the wells depends on the content of aggressive carbon dioxide in water and its impact on the steel elements. The highest values of this parameter were observed in water produced by well $\mathrm{c}$. The remaining indices characterizing water quality remain on the level of hydrogeochemical background.

\section{DESIGN OF INTAKE WELLS}

The wells of the "Grodzisko" intake were designed in view of the geological and hydrogeological conditions in this area (multi-grain sands, gravel-mix, gravel) and availability of 
various types of materials for casing columns and filter. For drilling these wells, steel casing columns, grid filters and fracture filters were applied. PVC pipes also started to be used in small quantities. The designs of wells $b, c$ and $d$ are presented in Table 3.

Table 3

Characteristics of intake wells b, c and d in the "Grodzisko" intake

\begin{tabular}{|c|c|c|c|c|c|c|c|}
\hline $\begin{array}{l}\text { Well } \\
\text { no. }\end{array}$ & $\begin{array}{c}\text { Year of } \\
\text { performing }\end{array}$ & $\begin{array}{l}\text { Depth } \\
\text { of well } \\
{[\mathrm{m}]}\end{array}$ & $\begin{array}{l}\text { Design } \\
\text { of well }\end{array}$ & $\begin{array}{c}\text { Depth of ca- } \\
\text { sing/filtration } \\
\text { column (and } \\
\text { active part) } \\
\text { [m] }\end{array}$ & $\begin{array}{l}\text { Diameter } \\
\text { of casing/ } \\
\text { filter } \\
{[\mathrm{m}]}\end{array}$ & $\begin{array}{l}\text { Length } \\
\text { of active } \\
\text { part of } \\
\text { filter } \\
{[\mathrm{m}]}\end{array}$ & $\begin{array}{l}\text { Extraction } \\
\text { in years }\end{array}$ \\
\hline \multirow[b]{2}{*}{$\mathrm{b}$} & \multirow[b]{2}{*}{1989} & \multirow[b]{2}{*}{114.0} & Steel casing & $0-70.0$ & 0.508 & & \multirow{2}{*}{$\begin{array}{l}23 \\
\text { (till the end } \\
\text { of produc- } \\
\text { tion) }\end{array}$} \\
\hline & & & $\begin{array}{l}\text { Perforated } \\
\text { liner filter } \\
\text { with nylon } \\
\text { grid }\end{array}$ & $\begin{array}{c}58.5-114.0 \\
(73.25-111.0)\end{array}$ & 0.298 & 29.15 & \\
\hline \multirow[b]{2}{*}{$\mathrm{c}$} & \multirow[b]{2}{*}{$\begin{array}{c}1970 \\
(1992 \\
\text { workover*) }\end{array}$} & \multirow[b]{2}{*}{$\begin{array}{c}127.5 \\
126.5^{*}\end{array}$} & Steel casing & $0-73.0$ & 0.508 & \multirow[b]{2}{*}{43.5} & \multirow[b]{2}{*}{$\begin{array}{c}22 \\
\text { (to the } \\
\text { second } \\
\text { workover - } \\
\text { replacement } \\
\text { of filter) } \\
25^{*}\end{array}$} \\
\hline & & & $\begin{array}{l}\text { Perforated } \\
\text { liner filter } \\
\text { with nylon } \\
\text { grid }\end{array}$ & $\begin{array}{c}58.9-127.5 \\
(74.1-124.5) \\
\\
59.3-126.5^{*} \\
\left(75.1-123.2^{*}\right)\end{array}$ & 0.298 & & \\
\hline \multirow[b]{2}{*}{ d } & \multirow[b]{2}{*}{1993} & \multirow[b]{2}{*}{113.0} & $\begin{array}{l}\text { Cemented } \\
\text { steel casing }\end{array}$ & $0-20.0$ & 0.610 & \multirow[b]{2}{*}{39.8} & \multirow[b]{2}{*}{24} \\
\hline & & & $\begin{array}{l}\text { Fractured } \\
\text { PVC filter to } \\
\text { the surface }\end{array}$ & $\begin{array}{c}0-68.0 \\
68.0-113.0 \\
(69.2-109.0)\end{array}$ & $\begin{array}{c}0.380 \\
\text { over filter } \\
0.250 \\
\text { filter }\end{array}$ & & \\
\hline
\end{tabular}

*After workover of well c in 1992

Wells b and c were made of steel pipes with a filter liner column. In 1992, well c was overworked, i.e. the corroded filter column was replaced with a new one, with the same type of filter and slightly longer active part. In well $d$, the casing and the filter column were made of PVC. The filter column reached the ground surface.

\section{EFFICIENCY OF WELLS}

Many years of extraction from the intake wells requires the evaluation of their technical condition and hydraulic efficiency, defined by the magnitude of hydraulic heads during the 
operation. The extraction in the "Grodzisko" intake is continuously observed for its work parameters. This and periodical TV inspections of the wells and measurement pumping jobs allowed for a complex evaluation of the condition in the intake.

\section{Observation of extraction parameters of the wells in the "Grodzisko" intake}

Production parameters of each well in the years of their operation are presented in the form of the plots illustrating the dependence of depression on the efficiency of the well. The operation of the well was analyzed from the beginning of their operation, including the workover of well c in 1992 [6].

In the course of extraction, the depression successively increased, with a resulting drop in efficiency. This was necessitated by the need to protect the pump aggregates against 'dry circulation'; another reason was the economic factor (increasing energy consumption of pump aggregates when water was produced at greater depths). Another cause of lower yield of steel-equipped wells with grid filter, i.e. wells b and c, was the sanding by the washed out pack and, in a further run, also sand from the aquifer. One of the causes of this effect were the perforations in the corroded filter parts. For the sake of maintaining the production of the well on the same level well c was reconstructed twice. During the first job, the gravel pack was reintroduced and a seal was placed in the annular space. The second reconstruction saw the replacement of the corroded filter with the pipes under and above it. In both cases, the time of operation between these jobs totaled about 10 years. In the second case, the yield of the well was successively lowered because of the constantly increasing depression. Establishing lower parameters of work in well c provided its stable and failure free operation for the next 25 years (Fig. 3).

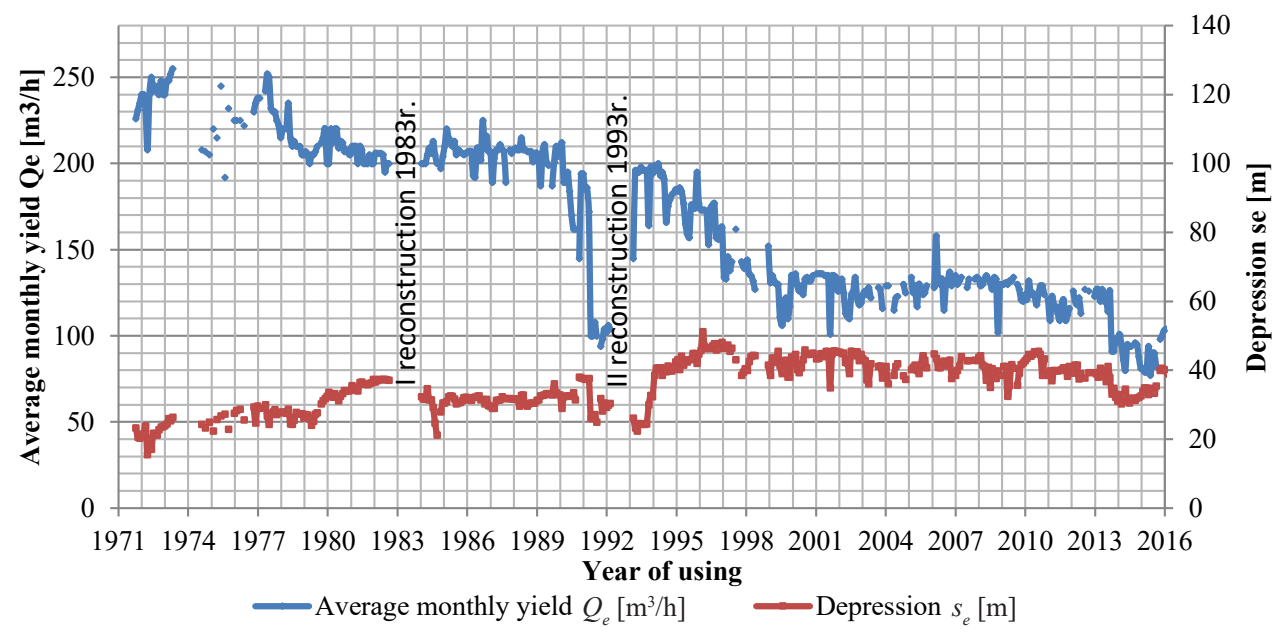

Fig. 3. Yield $Q_{e}\left[\mathrm{~m}^{3} / \mathrm{h}\right]$ and depression $s_{e}[\mathrm{~m}]$ in particular years of work of well c

The sanding of well $\mathrm{b}$ was caused by the damaged filtration grid and corrosion of the casing. The production yield of the well was reduced by $75 \%$ already after three years of 
operation (Fig. 4). Analogous to well c, the lower-rate extraction stopped the increasing tendency of depression, which helped further operation of the well on a uniform, economic level. In the last year of operation, sanding reappeared, which meant that the intaking of water with this well had to be stopped and the well liquidated.

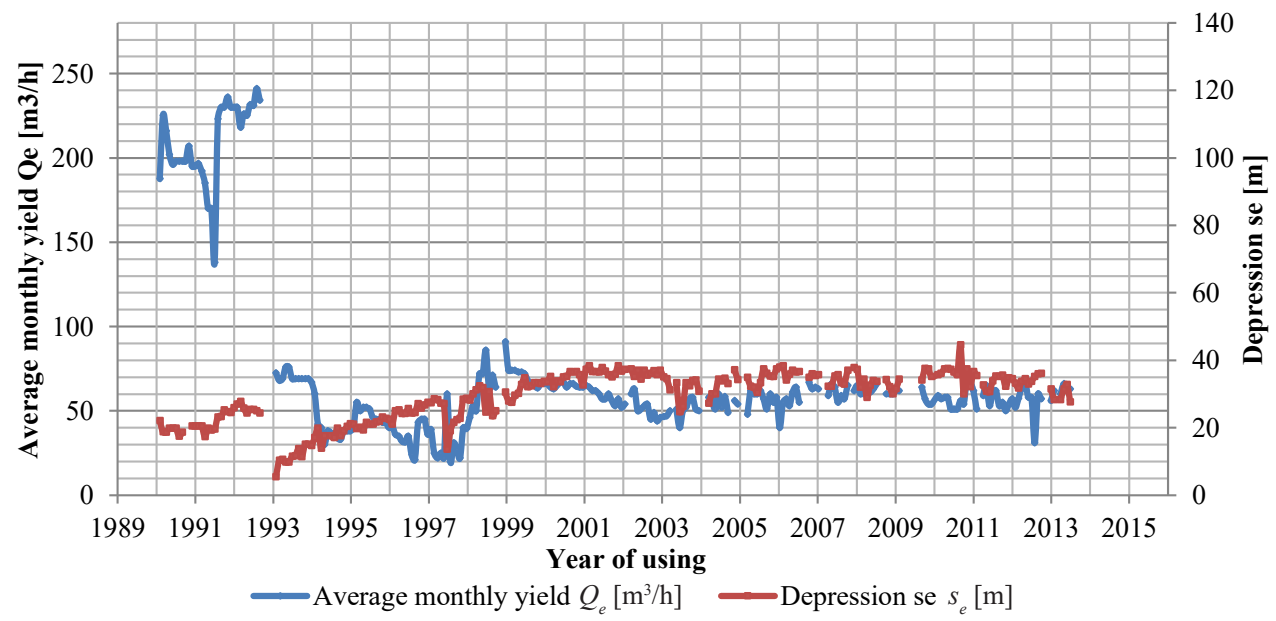

Fig. 4. Yield $Q_{e}\left[\mathrm{~m}^{3} / \mathrm{h}\right]$ and depression $s_{e}[\mathrm{~m}]$ in particular years of work of well b

Well $\mathrm{d}$ has operated flawlessly over the entire period of its activity. The increase of the depression with a concurrent drop of production rate is similar as in steel-design wells, though much slower (Fig. 5).

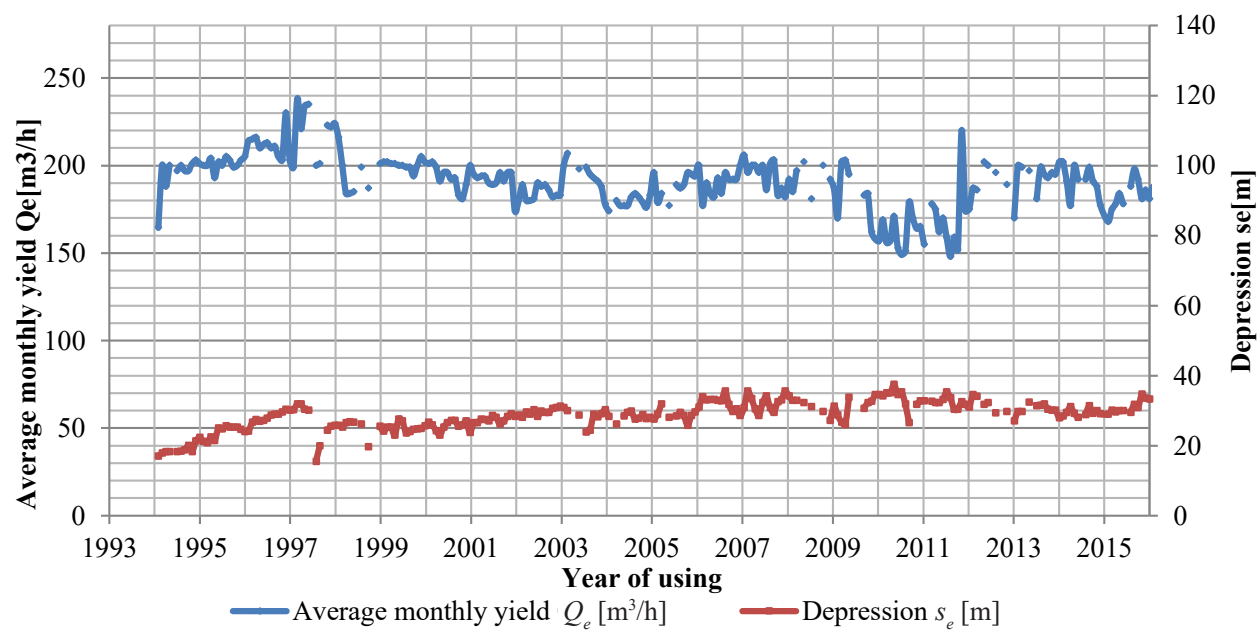

Fig. 3. Yield $Q_{e}\left[\mathrm{~m}^{3} / \mathrm{h}\right]$ and depression $s_{e}[\mathrm{~m}]$ in particular years of work of well d 


\section{TV inspection of wells}

The visual evaluation of the well's interior allows one to currently see its technical condition. In the "Grodzisko" intake the TV inspections were performed during the replacement of pump aggregates, at least every 3 years, and in emergency situations (e.g., sand in the pumped water). The successive inspection films were interpreted and compared to establish the state of the clogging of well filters (visually), degree of corrosion of wellbore elements and the soil slides in each of the wells.

After performing TV inspections in well $b$ the source of sanding was located, which occurred in the place of corroded pipe connections, and the broken filter grid (no grid) in its lower part. Last year, the soil slide increased by about $5.5 \mathrm{~m}$.

Over the last 10 years, when the inspections were performed regularly, the soil slides were not observed to increase in wells $\mathrm{c}$ and $\mathrm{d}$. The visual evaluation of the piping in the well revealed that the PVC construction underwent clogging to a much lesser degree than its steel equivalent.

\section{Well pumping}

For the sake of determining the hydraulic efficiency of the wells and present hydrogeological parameters of the Quaternary aquifer, 4-stage pumping jobs were performed in the ongoing wells (c and d), as presented in Figure 5.

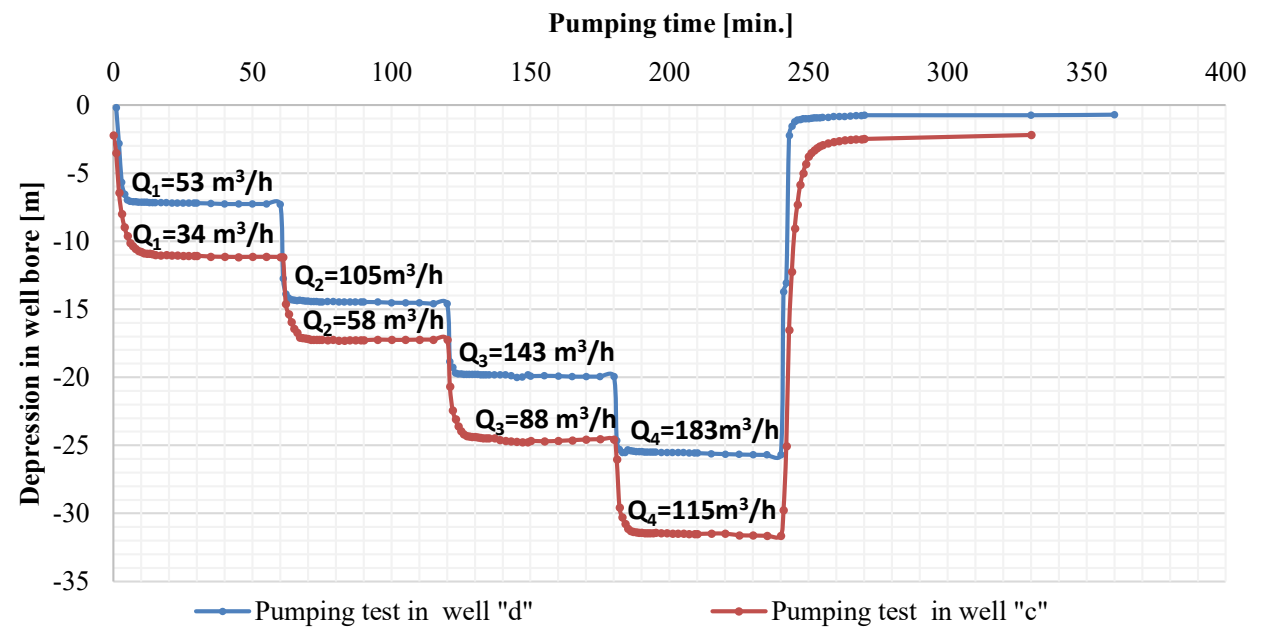

Fig. 5. Plot $s=f(t)$ for measurement pumping jobs performed in the operational wells of the "Grodzisko" intake

The original initial resources in place (established during extraction) were listed to visualize the hydraulic efficiency of the well. 


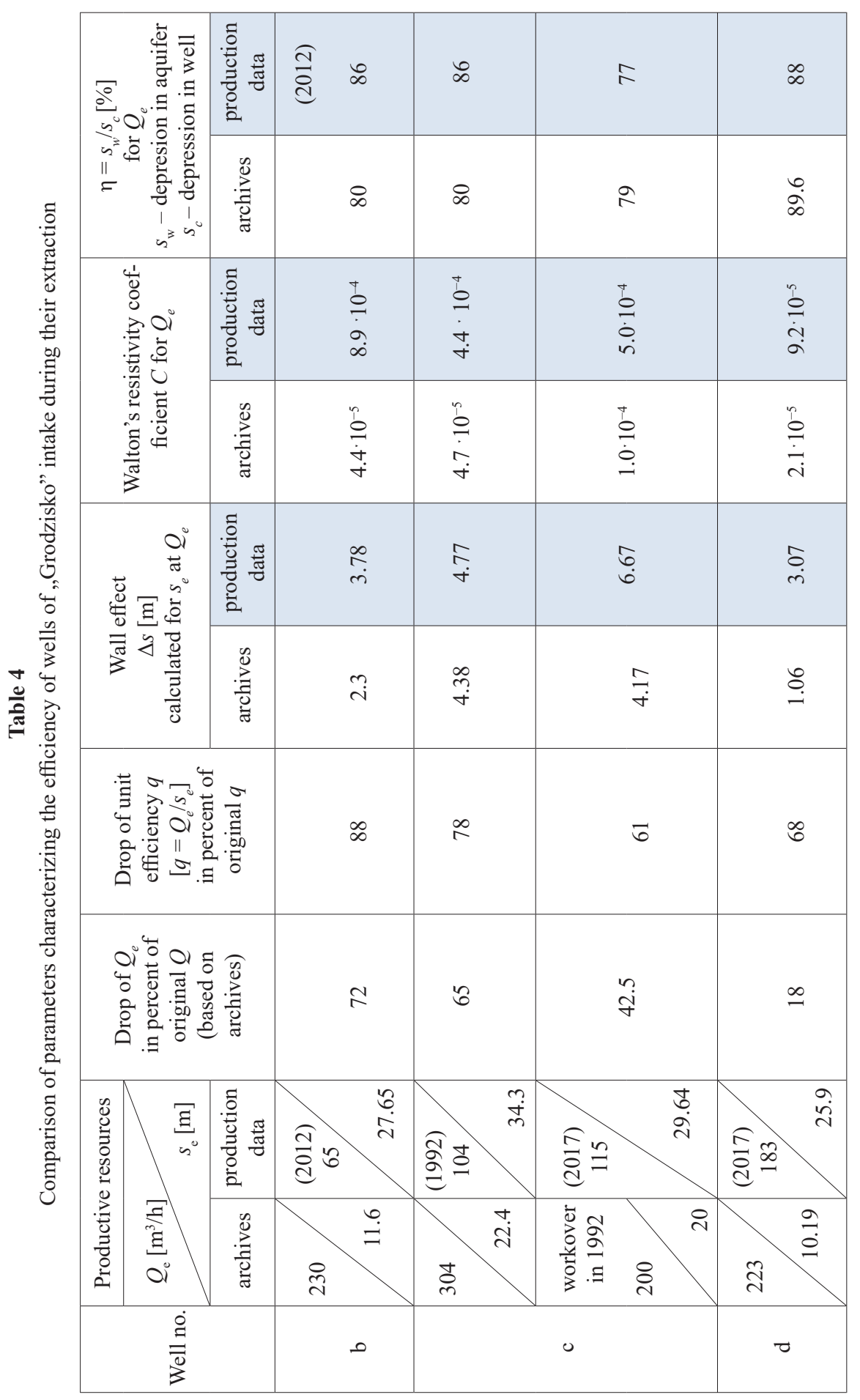


The varying values of unit yield and approximate hydraulic drop, calculated with Abramov's equation (3), were also presented [1]:

$$
\Delta s=0.01 \alpha \sqrt{\frac{Q s}{k F}}
$$

where:

$$
Q-\text { yield of well }\left[\mathrm{m}^{3} / \mathrm{d}\right]
$$

$s-$ depression in well [m],

$k-$ filtration coefficient $[\mathrm{m} / \mathrm{d}]$,

$F-$ active surface of filter $\left[\mathrm{m}^{2}\right]$,

$\alpha$ - empirical coefficient (6-25), which depends on the well's design; for perforated filters and fractured filters it equaled to 6-10; for grid filter and gravel filter it totaled to $15-25$; in the case of partially penetrating wells this coefficient oscillated between $1.25-1.5$ or was higher.

For wells band $\mathrm{c}$ the assumed value totaled to 20 , and 10 for well $\mathrm{d}$.

The hydraulic efficiency of a well was evaluated by comparing changes of coefficient of nonlinear resistivity during extraction in the near well zone $\mathrm{C}$ and depression measured in the well to depression calculated for aquifer $\eta$ [4]. The calculations made use of archival data from pumping, data from the final stage of extraction in well b and before workover in well c, as well as the results of multistage pumping in the operational wells in 2017. The results are listed in Table 4.

A considerable drop of production efficiency was observed in wells $b$ and $c$ which are equipped with steel elements, where the yield was reduced by at least $65 \%$ after about 20 years of operation. After renovation, well c could be used further though at lower work parameters, despite the applied longer filter section. In these wells the increase of wall effect and resistivity coefficient $C$, showing to the aging of the well, mainly due to the advancing filter clogging, could also be observed. In the first 20 years of operation, the efficiency of a well with a steel construction (b and c) was on a similar level, i.e. about $86 \%$.

The least decrease of production yield and unit yield over 25 years of exploitation was noted in well $\mathrm{d}$.

\section{CONCLUSIONS}

1. The applied well design determined the time of its production, mainly because of the resistance to the aging processes, the scale and intensity of which depend on local hydrochemical conditions. After over 20 years of extraction, the steel construction revealed advanced corrosion and therefore were not fit for further operation. As a result of the generated perforations in the filter column, the well started to become sanded. Consequently, the well either had to be renovated or production stopped. Therefore the longevity of this type of construction in the presented hydrogeological conditions can be assessed at about 25 years.

2. In the case of the 'Grodzisko' intake, the replacement of steel pipes with PVC pipes basically eliminated the corrosion problems, elongating the life of the well. Additionally, the 
introduction of the ultrafilter column and leading it to the surface eliminated the problem of sanding caused by washing out of the pack.

3. Many years of extraction changed the hydrogeological conditions in the aquifer, especially in the near well zone, which considerably limited the availability of water extraction in amount of the determined admissible volume of extracted groundwater. Moreover, the deterioration of the technical condition of the construction due to the aging of the well (corrosion of pipes, filter clogging) resulted in the lower work parameters of the well. With the progressing production an increase of depression was observed in the wells and of wall effect, showing a drop of efficiency in the well, mainly by the increase of flow resistivity in the filter and in the near filter zone.

4. Maintaining production abilities was most frequently connected with the growing depression, which accelerated aging processes with the progressing production. The longevity of the well could be extended by adjusting the work parameters of the well; the hydraulic resistivity should minimize the aging processes, mainly clogging and corrosion due to the higher flow rates through the filter.

5. The operation of the well should be observed in a complex way with current evaluation of the hydraulic efficiency of work of the well and technical inspection to diagnose the aging processes, failures in the active part of the filter etc.

\section{REFERENCES}

[1] Haładus A., Kulma R.: Dynamika wód podziemnych. Przykłady obliczeń. Cz. 2. Dopływy do ujęć wód podziemnych. Wydawnictwa AGH, Kraków 2014.

[2] Houben G., Treskatis Ch.: Regeneracja studni. Oficyna Wydawnicza Projprzem - Eko, Bydgoszcz 2004.

[3] Mizera J., Deska A., Malina G.: Zmiany parametrów hydrogeologicznych pod wpływem eksploatacji ujęć wód podziemnych $w$ rejonie Częstochowy. Problemy wykorzystania wód podziemnych w gospodarce komunalnej. Materiały na XIII sympozjum naukowo-techniczne „Problemy eksploatacji wód podziemnych”. Częstochowa 2000, pp. 44-50.

[4] Gonet A., Macuda J., Zawisza L., Duda R., Porwisz J.: Instrukcja obstugi wierceń hydrogeologicznych. Wydawnictwa AGH, Kraków 2011.

[5] Turek S. (red. nauk.): Poradnik hydrogeologa. Wydawnictwa Geologiczne, Warszawa 1971.

[6] Materiaty archiwalne i dane eksploatacyjne dotyczace studni ujęcia wód podziemnych „,Grodzisko”, 1956-2017. 